\title{
Efficacy of MRI in the differential diagnosis of odontogenic keratocyst: literature review
}

- Erika Antônia dos Anjos Ramos Department of Stomatology, Radiology, Faculty of Odontology, Sao Paulo University, Sao Paulo, Brazil - Fernando Amorim Mendonça Alves Department of Stomatology, Radiology, Faculty of Odontology, Sao Paulo University, Sao Paulo, Brazil • Cesar Angelo Lascala Department of Stomatology, Radiology, Faculty of Odontology, Sao Paulo University, Sao Paulo, Brazil • Andre Antonio James School of Dentistry, University of Sao Paulo, Sao Paulo, Brazil • Eduardo Massaharu Aoki Department of Stomatology, Radiology, Faculty of Odontology, Sao Paulo University, Sao Paulo, Brazil

ABSTRACT | According to the World Health Organization (WHO 2017), the odontogenic keratocyst (OKC) is classified as an odontogenic developmental cyst, with origins from the cellular remnants of the dental lamina. The characteristics of a high rate of cell proliferation, relapse and aggressive growth guide the choice of the type of surgical treatment for the lesion and, consequently, the prognosis. The use of Magnetic Resonance Imaging (MRI) for the differential diagnosis of odontogenic lesions does not replace anatomopathological examination, but the types of protocols already described illustrate the influence of these different protocols on the qualitative and quantitative description of keratocysts. We conclude that magnetic resonance imaging is valid as a tool to aid diagnosis of odontogenic lesions, especially for differential diagnosis studies between odontogenic keratocysts and ameloblastomas.

DESCRIPTORS || Odontogenic Keratocysts; MRI; Odontogenic Cyst; Ameloblastoma.

RESUMO | Eficácia da RM no diagnóstico diferencial de ceratocisto odontogênico: revisão de literatura • De acordo com a Organização Mundial de Saúde (OMS, 2017), o ceratocisto odontogênico (CO) é classificado como um cisto odontogênico de desenvolvimento, com origem nos restos celulares da lâmina dentária. A alta taxa de proliferação celular, recaída e crescimento agressivo direciona a escolha do tipo de tratamento cirúrgico para a lesão e, consequentemente, para seu prognóstico. $\mathrm{O}$ uso da ressonância magnética (RM) para o diagnóstico diferencial das lesões odontogênicas não substitui os exames anatomopatológicos, mas os tipos de protocolos já descritos ilustram a influência desses diferentes protocolos na descrição quantitativa e qualitativa dos ceratocistos. Concluímos que a ressonância magnética é válida como ferramenta de auxílio para o diagnóstico de lesões odontogênicas, principalmente em estudos de diagnóstico diferencial entre ceratocistos odontogênicos e ameloblastomas.

DESCRITORES | Ceratocistos odontogênicos; RM; Cisto odontogênico; Ameloblastoma.

CORRESPONDING AUTHOR | • Erika Antônia dos Anjos Ramos Department of Stomatology, Radiology, Faculty of Odontology, Sao Paulo University • Avenue Prof. Lineu Prestes 2227, Butantã, São Paulo, SP, Brazil • 05508-000 E-mail: erika.antonia.ramos@usp.br

- Received Feb. 5, 2018 • Accepted Apr. 24, 2018

- Dol http://dx.doi.org/10.11606/issn.2357-8041.clrd.2018.142696 


\section{INTRODUCTION}

The Odontogenic Keratocysts (OKC) is a benign lesion displaying a high prevalence worldwide with its occurrences being greater than $10 \%$ of odontogenic cysts. ${ }^{1-3}$ Historically, keratocysts has belonged to different classifications by WHO due to its specific histological characteristics associated with an aggressive clinical behavior. Philipsen ${ }^{4}$ was the first researcher to observe cystic characteristics of the lesion. He used the term "keratocyst" to allude to any type of cyst of the jaw that had representative keratin formation. However, when compared to other odontogenic cysts, the researcher observed differences and similarities to neoplasms such as: aggressive growth, high rates of relapse and high potential for cell differentiation. ${ }^{4,5}$ Thus, in 2005 the WHO, named the lesion as "Odontogenic Keratocystic Tumor" being the lesion, classified as a benign neoplasm.

In 2005, regarding the new classification and terminology, new research sought to understand the potential for expansive growth and high rate of cell proliferation that characterized it as a tumor. ${ }^{3}$ Thus, research using genetic mapping and immunohistochemical reactions indicated that in addition to the $p 53$ mutation, there was also the PTCH1 gene mutation and poor protein regulation. Confirmation of the presence of changes in the PTCH1 gene, both in isolated cases of OKC and cases with Gorlin syndrome, made WHO in 2017 re-establish the nomenclature of "odontogenic keratocyst", consequently classifying the OKC as an odontogenic cyst due to this mutation also being present in the other odontogenic cysts., ${ }^{3,6,7}$ With the paradox of both cystic and neoplastic similarities, OKC is known as a lesion originated from remnants of the dental lamina. In routine radiographic examinations, such as panoramic radiography, the identification of a cyst is relatively simple. However, the definitive diagnosis is only determined with anatomopathological examination. This is because other pathological entities such as ameloblastomas and keratocysts have similar radiographic features. Among these characteristics, the multilocular aspect, sclerotic borders and the radiolucency of the lesion are highlighted. ${ }^{8}$

However, it is important to emphasize that the treatment of each lesion requires different approaches. Keratocysts treatment usually requires enucleation followed by curettage. In some cases, marsupialization is required. On the other hand, ameloblastomas, due to more aggressive features, in some situations require block resection of the affected area with a safety margin. Researchers discuss immediate reconstruction by graft after resection on specific mandibular areas such as angle because some mandibular area and the size of bone defect is challenge to the surgeons. Thus, for these lesions there are different complexities to surgical management, sometimes there is a specific treatment. ${ }^{9-12}$

Magnetic resonance imaging is a technique that has great ability to differentiate soft tissues by working with radiofrequency (RF) signals from different levels of tissue magnetization. This magnetization can vary according to the number of hydrogen protons present in each tissue, field strength and also according to the type of chemical bonding in the molecules of the tissue among other factors. In order to increase capacity for contrast resolution, in addition to observing the different levels of magnetization of the tissues (T1-weighted images and T2-weighted images), diffusion-weighted images (DWI) can be used. Some studies, after confirming the lesions by anatomopathological examination, were directed to the purpose of performing a differential diagnosis of keratocysts through the use of magnetic resonance imaging. ${ }^{8,14-17}$

Thus, the aim of this study is to review studies that have applied magnetic resonance imaging as a tool for differentiating OKC from ameloblastomas. 


\section{Objective}

To investigate the potential of MRI in differentiate OKC and ameloblastoma.

\section{MATERIAL AND METHODS}

The following descriptors were used to search the Medline- United States National Library of Medicine (PubMed) database: odontogenic keratocyst, MRI, Magnetic Resonance and odontogenic cyst within the period between 1990 and 2017 October. The search found 30 English-language articles, resulting in the selection of 14 journals. The other journals were eliminated because they did not use MRI as a tool for keratocyst diagnosis.

\section{RESULTS}

\section{Odontogenic keratocyst $x$ ameloblastoma: differential diagnosis}

Keratocysts and ameloblastomas are benign odontogenic lesions with aggressive behavior and a high possibility of local recurrence. Table 1 shows some clinical similarities (etiology, asymptomatic nature, prevalence in the posterior region of the jaw of young patients and radiolucent areas with welldefined borders) between the pathological entities, but these lesions have different prognoses and require different types of surgical treatment. ${ }^{1}$

Thus, imaging examinations such as magnetic resonance imaging, through the use of protocols of resonance and contrast techniques, help to describe the content of lesions and, therefore, provide complementary characteristics for differential diagnosis between these two lesions. ${ }^{13,15,16,17}$

Srinivasan et al. ${ }^{17}$ do not exclude the importance of anatomopathological examination for diagnostic determination. On the contrary, they suggest MRI images as a complementary diagnosis that helps to compose a "gold standard" for diagnosis, due better identification of the limits of the lesion that requires surgical treatment.

Table 1 | Comparison between odontogenic keratocyst and ameloblastoma.

\begin{tabular}{|c|c|c|}
\hline WHO Classification 2017 & Odontogenic Keratocyst (Developmental Odontogenic Cyst) & Ameloblastoma (Epitelial Odontogenic Tumor) \\
\hline Etiology & Remnants of dental lamina & Remnants of dental lamina \\
\hline Quantitative Prevalence & $\begin{array}{l}5-15 \% \text { of all odontogenic cysts } \\
30 \% \text { of odontogenic tumors }\end{array}$ & $10-18 \%$ odontogenic tumors \\
\hline Qualitative Prevalence & $\begin{array}{l}\text { Male } \\
2^{\text {nd }} \text { and } 3^{\text {rd }} \text { decade }\end{array}$ & $\begin{array}{l}\text { - Male and Female } \\
\text { - } 2^{\text {nd }} \text { decade }\end{array}$ \\
\hline Localization & - Mandible: posterior region, ramus & - Mandible: posterior region, ramus and body \\
\hline Clinical Considerations & - Asymptomatic & - Asymptomatic \\
\hline Surgical Treatment & $\begin{array}{l}\text { - Decompression } \\
\text { Enucleation and Curettage } \\
\text { - Marsupialization }\end{array}$ & $\begin{array}{l}\text { - Decompression } \\
\text { - Marsupialization } \\
\text { - Resection with margin of safety }\end{array}$ \\
\hline Radiographic Features & $\begin{array}{l}\text { Radiolucent area, with well defined sclerotic margins } \\
\text { - } \text { Cortical expansion } \\
\text { - Senerally unicystic } \\
\text { - Associated with or not with an impacted tooth }\end{array}$ & $\begin{array}{l}\text { Radiolucent area, with well defined margins } \\
\text { with regions of bone septum } \\
\text { Cortical expansion } \\
\text { - Unicystic or multicystic } \\
\text { Associated with or not with an impacted tooth }\end{array}$ \\
\hline $\begin{array}{l}\text { Histopathological } \\
\text { Examination }\end{array}$ & Determinant & Determinant \\
\hline Histological Features & $\begin{array}{l}\text { Cystic feature } \\
\text { Stratified squamous epithelium Parakeratinized, cystic } \\
\text { lumen filled with a material derived from keratin. }\end{array}$ & $\begin{array}{c}\text { Unicystic luminal (epithelium of the } \\
\text { ameloblastoma), unicystic intraluminal (epithelium } \\
\text { in the cyst cavity) and wall (invasion of cyst wall); } \\
\text { Solid/multicystic; } \\
\text { Peripheral desmoplasia }\end{array}$ \\
\hline
\end{tabular}


Due to the asymptomatology of the lesion, the initial phase of odontogenic keratocysts and ameloblastomas are considered "radiographic finding”. At this time, an early diagnosis of these lesions is possible ${ }^{8}$, therefore avoiding the aggressive growth and the pathological expansion of these lesions. For an early and accurate diagnosis, MRI features help in the differential diagnosis of unilocular cysts such as simple bone cysts vs odontogenic cysts, keratocysts vs odontogenic cysts vs ameloblastomas, as well as for the differentiation of various types of ameloblastomas. ${ }^{16,18,20}$ In other words, the protocols for MR range from less complex cystic lesions to more specific subtypes of pathological entities, thereby demonstrating the importance of the applicability of this resource in patient care centers.

Depending on the clinical manifestation, if the lesions display more specific radiographic features, such as the intraosseous septa of a multicystic ameloblastoma; the "radiologists as well as the surgeon will not find it difficult to identify them". ${ }^{16}$ Sumi et al. ${ }^{16}$, for example, cite that even though odontogenic keratocysts (unilocular type) and ameloblastomas (multicystic type, honeycomb features) share a radiolucent area as a common characteristic, they are not difficult to radiographically diagnose. Difficulty of identification appears when these lesions are associated with other less classic variations such as multicystic keratocysts and when it is necessary to differentiate the unilocular OKC variation from the unicystic ameloblastoma. Thus, other researchers have suggested the use of MRI images to quantitatively and qualitatively assess intracapsular content, bearing in mind that both OKC and unicystic ameloblastomas have solid content and that other types of ameloblastoma may contain liquids..$^{18-22}$

Srinivasan et al. ${ }^{17}$ have shown the utility of MRI images for the differential diagnosis among subtypes of unicystic ameloblastomas. Through the use of contrast techniques, ameloblastic lesions appear to be mixed (solid and cystic), being predominantly cystic in some cases and purely cystic in others. When these ameloblastomas have cystic variants, keratocysts should be part of the differential diagnosis. ${ }^{13,16,19}$

Probst et al. ${ }^{8}$ reported the challenge in past studies of differentiating OKC by MR imaging. The authors stated that differentiation is possible by establishing parameters to be used in image acquisition, thus allowing for a better differential diagnosis between odontogenic lesions.

\section{Conventional MRI with or without contrast}

\section{When contrast is useful in MRI?}

The limitations of conventional radiographic techniques for the differential diagnosis of some lesions and the possible errors of diagnosis between OKC and ameloblastomas have proven the value of the complementary use of magnetic resonance imaging, as well as an incisional biopsy for anatomopathological examination. ${ }^{8,13}$

Minami et al..$^{13}$ described findings of odontogenic keratocysts, ameloblastomas, and odontogenic cysts analyzed by MRI using a $10 \mathrm{ml}$ ( $5 \mathrm{mmol}$ ) injectable builder. It was possible to define the characteristics of these lesions, such as (Figure 1): lesion boundaries / walls, contrast enhancement of walls, description of internal lesion content and type of interaction of magnetic signals in $\mathrm{T} 1$ and T2. Clearly, OKC showed a cystic structural pattern with a typical thin wall with contrast enhancement, presence of heterogeneous cystic content in 89\% $(n=17)$ of the cases and identification of different values of MR signals intensity for T1 / T2.

Minani et al. ${ }^{13}$ used a total of 19 patients with confirmed diagnosis for OKC. 17 of these cases were shown to have heterogeneous content: 6 cases in T1 images, 3 cases in T2 images and 8 cases in T1 and T2 images. Regarding the intensity of the signals, there 
was no precise unanimity, since the descriptions of the lesions were: $36.8 \%(n=7)$ with T1 in hyposignal and T2 in hypersignal; $31.5 \%(\mathrm{n}=6)$ with $\mathrm{T} 1$ in iso or hypersignal and T2 in hypersignal; 10.5\% $(\mathrm{n}=2) \mathrm{T} 1 \mathrm{in}$ iso or hypersignal and isosignal T2; and 21.0\% of CO ( $\mathrm{n}=4$ ) with hyposignal T1 and isosignal T2.

The ameloblastic lesions were characterized in their totality $(\mathrm{n}=11)$ as: mixed, thick walled structures, with homogeneous cystic content in the presence of contrasting. Furthermore, these lesions were classified according to signal intensity as hyposignal in $\mathrm{T} 1$ and hypersignal in $\mathrm{T} 2$. This was demonstrated by $81.8 \%(\mathrm{n}=9)$ of cases showing strong contrast enhancement of their walls. In other words, they obtained information similar to other international studies in relation to the description of MRI images for ameloblastomas. ${ }^{21,23}$ In addition, besides the descriptive contribution to a better understanding of the images of these two lesions, Minami et al. ${ }^{13}$ contributed with the observation that "to visualize odontogenic keratocyst content, T2 relaxation times tend to be relatively shorter than for the visualization of ameloblastoma contents."

If we compare contrasted conventional MR images of Minami et al..$^{13}$ with those of Sumi et al. ${ }^{16}$, who both structurally described the walls of the OKC and the ameloblastoma, one will encounter concordance and disagreement. Both researchers identified the ameloblastoma as a benign tumor with a solid wall, suggesting the maintenance of the logic that the walls of the OKC are thinner in relations to the thicker and more solid walls of the ameloblastoma. However, in 1996, Minami et al. ${ }^{13}$ recorded 100\% ( $\mathrm{n}=11$ ) of ameloblastomas as mixed structures; while in 2008, the authors suggested a more solid structural appearance for this same lesion. Despite the presence of contradictions over the structural features of the ameloblastoma, both articles presented OKC images indicating a "ring corresponding to cystic walls". Moreover, in relations to signal intensity, they registered isosignal $\mathrm{T} 1$ / $\mathrm{T} 2$ for the $\mathrm{OKC}$, and hyposignal T1 and hypersignal T2 for the ameloblastoma.
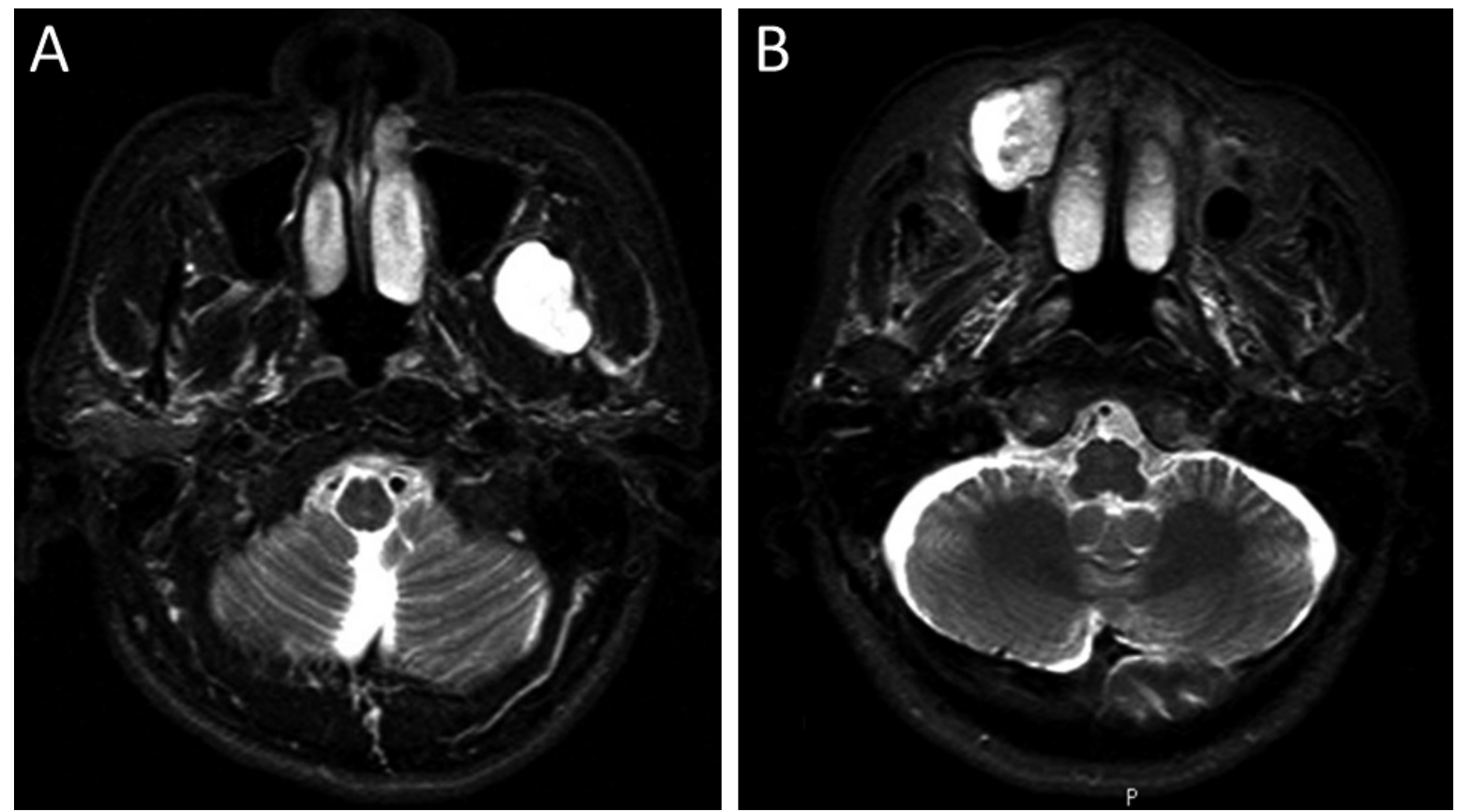

Figure 1 || MR images to illustrate some comparative aspects between OKC and Ameloblastoma. (A) OKC in the left mandible. Axial $\mathrm{T}_{2} \mathrm{~W}$ image shows the lesion with cystic structural with homogeneous high signal intensity. (B) Ameloblastoma in the right maxilla. Axial $\mathrm{T}_{2} \mathrm{~W}$ image shows the lesion with mixed aspect, enhancement of solid parts with heterogeneous high signal intensity. 


\section{Diffusion-Weighted MR}

Imaging (DWI) and Apparent

Diffusion Coefficient (ADC)

Diffusion imaging (DWI), a modified T2 weighted technique, allows the analysis from the randomized movement of water molecules in tissues, which is quantitative measured by signal attenuation and quantitatively by employing gross apparent diffusion coefficient (ADC) values. Tissue may exhibit free or restricted diffusion depending on tissue cellularity, microarchitecture and membrane integrity. ${ }^{23}$

Considering that studies with conventional contrast MR have corroborated towards a better understanding of odontogenic keratocysts and ameloblastomas. Sumi et al. ${ }^{15}$ compared contrast-enhanced MR images. In their study, gadolinium $0.1 \mathrm{mmol} / \mathrm{kg}$ body mass was introduced into 16 patients with confirmed diagnosis of odontogenic keratocyst $(n=7)$ and ameloblastoma $(n=9)$. Also, DWI were obtained, which highlighted for the first time the importance of the apparent coefficient of diffusion (ADC) for a better mapping of these lesions. ${ }^{13,19}$

Results obtained by Sumi et al. ${ }^{16}$ explained that protocols using DWI for acquiring images are influenced by both physical (temperature, pressure and viscosity) and physiological parameters of the lesion (extracellular matrix and fluids). Changes in these parameters result in changes in pixel intensity during the DWI sequence. This in turn, alters signal intensity; consequently, influencing the acquisition of images of spaces containing intracellular and extracellular water. Therefore, the interaction of the signals with the specific fluids within the OKC and the ameloblastoma provides an ADC mapping. This demonstrated that the non-enhanced images of the two lesions are different, in consideration of the fact that these lesions have distinct physiological and histological properties, such as fluid rich in keratin and monosaccharides in the case of the OKC and a less specific protein rich fluid in the case of the ameloblastoma. ${ }^{17,18}$ It is suggested that this composition changes the intraluminal osmotic pressure. The relevance of this is shown by the fact that the higher the viscosity of the fluids, the lower the levels of non-enhancement of the lesions during ADC mapping.

Succinctly, Sumi et al. ${ }^{16}$ have contributed by observing that ADC measurements can be specific for each lesion. This especially stands true for ameloblastomas, where images in DWI have demonstrated similarities to the histological structure of the lesion seen through an electron microscope at 10x magnification.

Utilizing DWI, Srinivasan et al. ${ }^{17}$ obtained contrasted images employing conventional MR and DW imaging. For the latter, they conducted both a qualitative analysis (type of interaction of the lesion with DW signals and the consequence of this in the visualization of the lesion on the ADC map) and a quantitative analysis (calculation of the values of the ADC measurements) of OKC and ameloblastomas.

Accordingly, Srinivasan et al. ${ }^{17}$ presents, in the form of conventional MRI images, OKC and ameloblastomas respectively as cystic and mixed lesions, hence agreeing with previous research. ${ }^{17,18}$

The T1 / T2 analysis for OKC is similar to research done by Minami et al. ${ }^{13}$ However, Minami et al. ${ }^{13}$ achieved better detailing of the images of ameloblastomas despite using conventional MRI images that may show overlapping. Moreover, they were able to divide these images into: predominantly cystic and purely cystic, thus providing better visualization of the cystic areas in $\mathrm{T} 1$ / T2. In addition, the researchers observed that the ADC mapping was different when comparing a cystic area to a solid area. This is due to the lesion's response to diffusion, consequently the values of ADC measurements for solid areas are less than those for cystic areas. The quantitative difference in ADC values allows for a precise and accurate differential diagnosis between OKC and ameloblastoma. ${ }^{16,17}$ 


\section{DISCUSSION}

The three changes in the classification of odontogenic keratocyst by WHO suggest that the peculiar characteristics of this lesion are of paramount importance for differential diagnosis and therefore, important to compose an adequate surgical treatment choice. ${ }^{3,6,10,11}$ The KOC can manifest itself as unilocular or multilocular form. The unilocular form has similarities with the unicystic ameloblastoma. ${ }^{16,17}$ The anatomopathological examination is indispensable for diagnosis confirmation. In addition, imaging tests such as panoramic radiography, computed tomography and magnetic resonance imaging are valuable tools for better understanding of these lesions. For some examples of OKC and ameloblastomas, MRI employing DWI proved to be a useful tool for differential diagnosis between these lesions..$^{16,17,19}$

Studies of OKC and ameloblastoma using conventional MRI ${ }^{13,18}$ using contrast (gadolinium) showed that the images produced with the use of contrast enhancement, especially of the walls of OKC and ameloblastomas, was presented as consistent. Accordingly, contrast enhancement was described as a factor for a proper differential diagnosis between the KOC and ameloblastoma. ${ }^{13,16}$ In some cases, MR images with contrast presented overlap imagenological features; thus contributing to possible diagnostic errors. ${ }^{17}$

Considering studies using conventional MRI and DWI of patients with OKC and ameloblastomas, we observe concordances in imagenological appearance described. These similarities include: the description of the aspect of the pathology, the specific signal intensity for each lesion and the numerical ADC values..$^{13,16-19}$ The protocols with conventional MR images with contrast application, studies have agreed with the presence of enhancement of the cystic walls for both lesions. Regarding the description of the lesions, OKC had different signal intensity patterns for $\mathrm{T} 1$ and
T2, while images of ameloblastomas were described in hyposignal for T1 and hypersignal for T2 ${ }^{13,16,18} \mathrm{In}$ the case of quantitative analysis, the authors agreed that OKC showed lower mean ADC values than ameloblastomas. ${ }^{17,19}$ Taking into account research which exclusively used patients with OKC lesions, the main similarity between these studies was the unanimous use of protocols utilizing contrast techniques with conventional MR examination. Nevertheless, there was no agreement on signal intensity values for OKC..$^{8,14,15}$ Hisatomi et al..$^{14}$, Van Rensburg et al. ${ }^{15}$ and Probst et al. ${ }^{8}$ found that $\mathrm{OKC}$ is identifiable in MR images (T1 / T2) in iso-hypersignal / hyposignal; iso-hyposignal / hypersignal and isosignal / hypersignal. Therefore, the advantages of the DWI technique are more sensitive for differential diagnosis because it involves both physical parameters (tissue structure) and physiological parameters (movement of water molecules), which are different based on the cellularity of each lesion.

The high values of sensitivity (100\%) and specificity (100\%) for differential diagnosis has helped to justify the use of MR-DWI as a technique for a more detailed description of lesions. ${ }^{17}$ This contributed to Sakamoto et al. ${ }^{19}$ investigating the applications of the DKI technique (Diffusion Kurtosis Imaging). DKI represents an evolution in the DWI technique; in which the parameters of the d-values (diffusion coefficient) and the k-values (excess kurtosis) would help to increase the accuracy of the DWI technique. ${ }^{17}$ Even with the evolution of the protocols for the use of MRI as a complementary exam for diagnosis of odontogenic lesions, limitations in current research have presented themselves in the form of difficulties of standardizing the signal intensity and the number of patients studied.

In summary, it was apparent that each research had one main result (Table 2); which suggests safe parameters for the use of MR imaging for differential diagnosis, despite the need for an "ideal" protocol 
for acquiring $\mathrm{ADC}$ values to better describe OKC. The importance of the standardization of a protocol guides the evolution of the differential diagnosis of other benign lesions, such as odontogenic cysts. These lesions still present difficulties to differentiate by MRI (conventional, DWI and DKI) due to similar cystic characteristics. ${ }^{17,19}$
In addition, the need for further research with a greater number of lesions measured in a standardized format (magnetic field and protocol) was also noted. This is essential to improve the use of MR-DWI images as a safe tool for complementary lesion description (such as invasive cellularity and limits of involved tissue) during the trans-operative period.

Table 2 | Comparative analysis of selected articles.

\begin{tabular}{|c|c|c|c|c|c|c|}
\hline $\begin{array}{c}\text { Author/ } \\
\text { Year }\end{array}$ & MR & Lesion (n) & Contrast & $A D C$ & DWI & $\mathrm{T} 1 / \mathrm{T} 2$ \\
\hline $\begin{array}{l}\text { Minami } \\
\text { et al. }{ }^{13} \\
1996\end{array}$ & $\begin{array}{c}\text { 0.064-T } \\
\text { (Toshiba America } \\
\text { MRI, San Francisco, } \\
\text { CA) } \\
\text { O.2-T } \\
\text { (Siemens-Asahi } \\
\text { Meditech, Tokyo, } \\
\text { Japan) }\end{array}$ & $\begin{array}{c}\text { OKC } \\
(n=19) \\
\text { Ameloblastoma } \\
(n=11)\end{array}$ & $\begin{array}{c}\text { OKC: } \\
\text { enhancement } \\
\quad(n=10) \\
\text { Ameloblastoma: } \\
\text { contrast } \\
\text { enhancement } \\
\text { in T1 }(n=9)\end{array}$ & No & No & $\begin{array}{c}\text { OKC } \\
\text { heterogeneous intensity, } \\
\text { - T1: hyposignal, } \\
\text { hypersignal } \\
\text { - T2: hyposignal } \\
\text { Ameloblastoma } \\
\text { homogeneous intensity, } \\
\text { - T1: hyposignal } \\
\text { - T2: hypersignal }\end{array}$ \\
\hline $\begin{array}{l}\text { Hisatomi } \\
\text { et al. }^{14} \\
2003\end{array}$ & $\begin{array}{c}1.5 \mathrm{~T} \\
\text { (Magnetom Vision; } \\
\text { Siemens, Erlangen, } \\
\text { Germany) }\end{array}$ & $\begin{array}{c}\text { OKC } \\
(n=7)\end{array}$ & $\begin{array}{c}\text { OKC: } \\
\text { enhancement of } \\
\text { margins }(n=3)\end{array}$ & No & No & $\begin{array}{c}\text { OKC } \\
\text { T1: hyposignal-hypersignal } \\
\text { T2: heterogeneous- } \\
\text { hypersignal }\end{array}$ \\
\hline $\begin{array}{l}\text { Van } \\
\text { Rensburg } \\
\text { et al. }^{15} \\
2003\end{array}$ & $\begin{array}{c}\text { 0,5T } \\
\text { (Gyroscan T5-NT; } \\
\text { Philips, } \\
\text { Netherlands) }\end{array}$ & $\begin{array}{c}\text { OKC } \\
(n=21)\end{array}$ & $\begin{array}{c}\text { OKC: } \\
\text { T1 without } \\
\text { epithelial } \\
\text { enhancement }\end{array}$ & No & No & $\begin{array}{c}\text { OKC } \\
\text { T1: heterogeneous with } \\
\text { hypo-isosignal } \\
\text { T2: hypersignal and } \\
\text { characteristic signal } \\
\text { heterogeneity = "Signal } \\
\text { drop out" }\end{array}$ \\
\hline $\begin{array}{l}\text { Sumi } \\
\text { et al. }^{16} \\
2008\end{array}$ & $\begin{array}{c}1.5 \mathrm{~T} \\
\text { (Master; Philips } \\
\text { Medical Systems, } \\
\text { Best, Netherlands) }\end{array}$ & $\begin{array}{c}\text { OKC } \\
(n=7) \\
\text { Ameloblastoma } \\
(n=9)\end{array}$ & $\begin{array}{c}\text { OKC: } \\
\text { no enhancement } \\
\text { Ameloblastoma: } \\
\text { enhancement of } \\
\text { walls }(n=9)\end{array}$ & $\begin{array}{l}\text { ADCs of lesions } \\
\text { not enhanced in } \\
\text { ameloblastomas } \\
\text { were significantly } \\
\text { higher than those of } \\
\text { unenhanced lesions } \\
\text { in OKC. }\end{array}$ & Yes & $\begin{array}{c}\text { OKC } \\
\text { T1: hypo-isosignal } \\
\text { T2: hypo-hypersignal } \\
\text { "fat-suppressed" }\end{array}$ \\
\hline $\begin{array}{l}\text { Srinivasan } \\
\text { et al. }^{17} \\
2012\end{array}$ & $\begin{array}{c}1.5 \mathrm{~T} \\
\text { (Avanto; Siemens, } \\
\text { Erlangen, Germany) }\end{array}$ & $\begin{array}{c}\text { OKC } \\
(n=5) \\
\text { Ameloblastoma } \\
(n=10)\end{array}$ & $\begin{array}{c}\text { OKC: } \\
\text { wall and septa } \\
\text { enhancement } \\
\text { Ameloblastoma: } \\
\text { enhancement of } \\
\text { solid parts }\end{array}$ & $\begin{array}{c}\text { OKC: } \\
\text { restricted difusion } \\
\text { Ameloblastoma: } \\
\text { - free diffusion in } \\
\text { cystic parts and } \\
\text { restricted diffusion in } \\
\text { solid parts } \\
\text { ADC values for } \\
\text { ameloblastoma } \\
\text { significantly higher } \\
\text { than ADC of CO. }\end{array}$ & Yes & $\begin{array}{c}\text { OKC } \\
\text { T1: hyposignal } \\
\text { T2: hypersignal } \\
\text { Ameloblastoma } \\
\text { - cystic areas with } \\
\text { hyposignal on T1, } \\
\text { hypersignal on T2; } \\
\text { - solid areas hyposignal } \\
\text { T1 iso-hypersignal T2 }\end{array}$ \\
\hline
\end{tabular}


Table 2 | Continuation

\begin{tabular}{|c|c|c|c|c|c|c|}
\hline $\begin{array}{c}\text { Author/ } \\
\text { Year }\end{array}$ & MR & Lesion (n) & Contrast & ADC & DWI & $\mathrm{T} 1 / \mathrm{T} 2$ \\
\hline $\begin{array}{l}\text { Fujita } \\
\text { et al. }^{18} \\
2013\end{array}$ & $\begin{array}{c}1.5 \mathrm{~T} \\
\text { (Magnetom Vision; } \\
\text { Siemens, Erlangen, } \\
\text { Germany) }\end{array}$ & $\begin{array}{c}\text { OKC } \\
(n=14) \\
\text { Ameloblastoma } \\
(n=26)\end{array}$ & $\begin{array}{c}\text { DCE-MRI } \\
\text { (two different } \\
\text { types of contrast) } \\
\text { - little } \\
\text { contribution } \\
\text { to differential } \\
\text { diagnosis }\end{array}$ & No & $\begin{array}{c}\text { No } \\
\text { (old equipment) }\end{array}$ & $\begin{array}{l}\text { OKC } \\
\text { Uniformity of useful signal } \\
\text { for differential diagnosis } \\
\text { (T1, T2 and STIR) }\end{array}$ \\
\hline $\begin{array}{l}\text { Probst } \\
\text { et al. }{ }^{8} \\
2015\end{array}$ & $\begin{array}{c}\text { 1.0-T } \\
\text { (Magnetom } \\
\text { Harmony; Siemens, } \\
\text { Erlangen, Germany) } \\
\text { 1.5-T unit } \\
\text { (Magnetom Vision; } \\
\text { Siemens, Germany) } \\
\text { 3.0-T } \\
\text { (Philips medical } \\
\text { systems, Hamburg, } \\
\text { Germany) }\end{array}$ & $\begin{array}{c}\text { OKC } \\
(n=10)\end{array}$ & $\begin{array}{l}\text { Enhancement } \\
\text { of walls with } \\
\text { hyposignal. }\end{array}$ & No & No & $\begin{array}{c}\text { OKC } \\
\text { T1: isosignal } \\
\text { T2: hypersignal }\end{array}$ \\
\hline $\begin{array}{l}\text { Sakamoto } \\
\text { et al. }{ }^{19} \\
2016\end{array}$ & $\begin{array}{c}\text { 3T } \\
\text { (Magnetom } \\
\text { Spectra, Siemens } \\
\text { Healthcare, } \\
\text { Erlangen, } \\
\text { Germany) }\end{array}$ & $\begin{array}{c}\text { OKC } \\
(n=6) \\
\text { Ameloblastoma } \\
(n=5)\end{array}$ & No & $\begin{array}{c}\text { Gross values of } \\
\text { D and ADC were } \\
\text { significantly higher } \\
\text { for ameloblastomas } \\
\text { than OKC } \\
\text { Gross values of } \\
\text { K and ADC were } \\
\text { significantly lower } \\
\text { for ameloblastomas } \\
\text { than OKC. }\end{array}$ & $\begin{array}{l}\text { Combination } \\
\text { of DKI } \\
\text { parameters can } \\
\text { increase the } \\
\text { effectiveness } \\
\text { of the } \\
\text { diagnosis when } \\
\text { compared with } \\
\text { ADC values. }\end{array}$ & No \\
\hline
\end{tabular}

\section{CONCLUSION}

MRI has shown potential in differentiating ameloblastomas from OKC by using ADC values.

\section{ACKNOWLEDGEMENTS}

The authors thank to Department of Oral and Maxillofacial Radiology, Okayama University Dental School/Japan for contributing to the sharing MR images (Figure 1).

\section{REFERENCES}

1. Servato JP, Prieto-Oliveira P, de Faria PR, Loyola AM, Cardoso SV. Odontogenic tumours: 240 cases diagnosed over 31 years at a Brazilian university and a review of international literature. Int J Oral Maxillofac Surg. 2013;42(2):288-93.

2. Harmon M, Arrigan M, Toner M, O’Keeffe SA. A radiological approach to benign and malignant lesions of the mandible. Clin Radiol. 2015;70(4):335-50.
3. Li TJ. The odontogenic keratocyst: a cyst, or a cystic neoplasm? J Dent Res. 2011;90(2):133-42.

4. Philipsen HP. Omkeratocyster (kolesteatomer) I kaeberne. Tandlaegebladet. 1956;60:963-80.

5. Browne RM. Investigative pathology of the odontogenic cysts. Boca Raton: CRC Press; 1991.

6. Wright JM, Vered M. Update from the 4th edition of the World Health Organization classification of head and neck tumours: odontogenic and maxillofacial bone tumors. Head Neck Pathol. 2017;11(1):68-77.

7. Pavelić B, Levanat S, Crnić I, Kobler P, Anić I, Manojlović S, et al. PTCH gene altered in dentigerous cysts. J Oral Pathol Med. 2001;30(9):569-76.

8. Probst FA, Probst M, Pautke C, Kaltsi E, Otto S, Schiel S, et al. Magnetic resonance imaging: a useful tool to distinguish between keratocystic odontogenic tumours and odontogenic cysts. Br J Oral Maxillofac Surg. 2015;53(3):217-22.

9. Pogrel MA, Jordan RC. Marsupialization as a definitive treatment for the odontogenic keratocyst. J Oral Maxillofac Surg. 2004;62(6):651-5; discussion 655-6. 
10. Carlson ER, Marx RE. The ameloblastoma: primary, curative surgical management. J Oral Maxillofac Surg. 2006;64(3):484-94.

11. Johnson OK, Sharma K. Ameloblastoma resection with immediate rib reconstruction: addressing the problem of mandibular angle and central bone bulk. Trop Doct. 2017;47(4):384-8.

12. Xavier SP, de Mello-Filho FV, Rodrigues WC, Sonoda CK, de Melo WM. Conservative approach: using decompression procedure for management of a large unicystic ameloblastoma of the mandible. J Craniofac Surg. 2014;25(3):1012-4.

13. Minami M, Kaneda T, Ozawa K, Yamamoto H, Itai Y, Ozawa $\mathrm{M}$, et al. Cystic lesions of the maxillomandibular region: MR imaging distinction of odontogenic keratocysts and ameloblastomas from other cysts. AJR Am J Roentgenol. 1996;166(4):943-9.

14. Hisatomi M, Asaumi J, Konouchi H, Shigehara H, Yanagi Y, Kishi K. MR imaging of epithelial cysts of the oral and maxillofacial region. Eur J Radiol. 2003;48(2):178-82.

15. Van Rensburg LJ, Paquette M, Morkel JA, Nortjé CJ. Correlative MRI and CT imaging of the odontogenic keratocyst: a review of twenty-one cases. Oral Maxillofac Surg Clin North Am. 2003;15(3):363-82.

16. Sumi M, Ichikawa Y, Katayama I, Tashiro S, Nakamura T. Diffusion-weighted MR imaging of ameloblastomas and keratocystic odontogenic tumors: differentiation by apparent diffusion coefficients of cystic lesions. AJNR Am J Neuroradiol. 2008;29(10):1897-901.

17. Srinivasan K, Seith Bhalla A, Sharma R, Kumar A, Roychoudhury A, Bhutia O. Diffusion-weighted imaging in the evaluation of odontogenic cysts and tumours. Br J Radiol. 2012;85(1018):e864-70.

18. Fujita M, Matsuzaki H, Yanagi Y, Hara M, Katase N, Hisatomi M, et al. Diagnostic value of MRI for odontogenic tumours. Dentomaxillofac Radiol. 2013;42(5):20120265.

19. Sakamoto J, Kuribayashi A, Kotaki S, Fujikura M, Nakamura S, Kurabayashi T. Application of diffusion kurtosis imaging to odontogenic lesions: Analysis of the cystic component. J Magn Reson Imaging. 2016;44(6):1565-71.

20. Yanagi Y, Asaumi J, Unetsubo T, Ashida M, Takenobu T, Hisatomi M, et al. Usefulness of MRI and dynamic contrast-enhanced MRI for differential diagnosis of simple bone cysts from true cysts in the jaw. Oral Surg Oral Med Oral Pathol Oral Radiol Endod. 2010;110(3):364-9.

21. Asaumi J, Matsuzaki H, Hisatomi M, Konouchi H, Shigehara $\mathrm{H}$, Kishi K. Application of dynamic MRI to differentiating odontogenic myxomas from ameloblastomas. Eur J Radiol. 2002;43(1):37-41.

22. Konouchi H, Asaumi J, Yanagi Y, Hisatomi M, Kawai N, Matsuzaki H, et al. Usefulness of contrast enhanced-MRI in the diagnosis of unicystic ameloblastoma. Oral Oncol. 2006;42(5):481-6.

23. Hisatomi M, Yanagi Y, Konouchi H, Matsuzaki H, Takenobu T, Unetsubo T, et al. Diagnostic value of dynamic contrast-enhanced MRI for unilocular cystic-type ameloblastomas with homogeneously bright high signal intensity on T2-weighted or STIR MR images. Oral Oncol. 2011;47(2):147-52.

24. Koh DM, Collins DJ. Diffusion-weighted MRI in the body: applications and challenges in oncology. AJR Am J Roentgenol. 2007;188(6):1622-35. 